\title{
CANNED ADAPTATIONS AND INTERNATIONAL SUCCESS OF TURKISH TV SERIES
}

\author{
Deniz Zorlu \\ Izmir Ekonomi Üniversitesi \\ deniz.zorlu@izmirekonomi.edu.tr
}

\begin{abstract}
This article examines Turkish TV series' recent success as canned programming primarily in newly developed and developing countries in Eastern Europe, the Balkans, the Middle East, South Asia, and South America through close textual analysis of a particularly popular Turkish adaptation, Bizim Hikaye (Our Story) (2017-2019) in comparison with its original, Shameless (2011-). I argue that Turkish series' emphasis on nostalgic and melancholic narrative frames make them particularly appealing in these regions, as they deal with relatable circumstances of swift and traumatic changes under neoliberalism. However, female protagonists are allowed only a limited range of roles because of the reliance on nostalgia, thus, ultimately serving to re-legitimize patriarchal relations of domination.
\end{abstract}

Keywords: neoliberal culture, nostalgia, melancholia, Turkish TV series, melodrama

\section{Introduction}

Turkish TV series have been screened in over 150 countries in the last decade, achieving resounding success in Eastern Europe, the Balkans, the Middle East, East Asia, and South America. Adaptations constitute a growingly notable part of the Turkish television industry, ${ }^{1}$ which adapts foreign television programs to local cultural priorities, while also successfully exporting them across the globe. This article focuses on the socio-cultural factors causing Turkish TV series to become successful ventures of canned television through close textual analysis of an adaptation, Bizim Hikaye (Our Story) (2017-2019) in comparison with its original, Shameless (2011-). In reformulating foreign scripts, Turkish adaptations resort to similar narrative and thematic formulas, which emphasize a nostalgic and melancholic longing for authenticity and purity. I argue that the textual characteristics of Turkish series render them specifically appealing for newly developed and developing countries, as they deal with relatable circumstances of rapid economic and socio-cultural transformations under conditions of neoliberalism.

Our Story is adapted from American Shameless that is, in turn, an adaptation from British Shameless (2004-2013). Our Story received high ratings in several countries and was voted as the best Turkish series of the year by viewers in Peru, Argentina, and Chile in 2019 at the Latin American Turkish Series Awards. ${ }^{2}$ Hence, the most successful television series of the year in a major market for Turkish television series is an adaptation. ${ }^{3}$ Our Story copies every major plot element of its originals, while thematically re-structuring them. The close comparative textual analysis of Our Story demonstrates in a crystallized manner the thematic particularities of Turkish adaptations and the reasons 
for their success as canned programming in a wide region of the world. I argue that the Turkish series' international appeal rests on the nostalgic and melancholic imagination, stressing the fragments of life that appear untouched by the currents of neoliberal socio-cultural change. Thus, Turkish canned television successfully packages and exports to newly developed and developing countries the nostalgia and melancholic attachment for an imaginary time of purity, simplicity, and authenticity.

I also demonstrate through the analysis of Our Story that this excessive reliance on nostalgia negatively affects Turkish series' gender politics in allowing only a limited repertoire of roles for their central female protagonists. It is argued that the Turkish TV series' appeal is partially caused by their strong female protagonists, who struggle against aspects of patriarchal relations of domination. ${ }^{4}$ The stories of these female protagonists, it is argued, provide a notable source of inspiration to women who can relate to their circumstances of life. The social realism of Turkish dramas, thus, constitutes a crucial aspect of their allure as canned programs. Yet, I argue that, despite their valuable yet partial criticisms of patriarchy, the nostalgic glorification of the large family and heterosexual romance, common themes of Turkish serials, severely delimit the representational possibilities of female protagonists, ultimately serving to re-package and re-legitimize patriarchy.

Myriad explanations are put forward to explicate the rising popularity of Turkish TV series, and nostalgia is an oftenmentioned cause in many analyses. I believe these studies neglect crucial aspects of this common nostalgic and melancholic characteristics of Turkish TV series, as they do not focus on the contemporary stream of events that lay the groundwork for the global affliction with nostalgic and melancholic narratives. In alignment with the literature on nostalgia, which posits that it is, in essence, a fascination with a largely imagined past created out of the needs of the present, ${ }^{5}$ this article identifies swift neoliberal socio-economic and cultural transformation as a common thread in explaining Turkish TV series' popularity. Furthermore, nostalgia is typically perceived as a positive or politically neutral attribute of Turkish TV series; thus, it is left unscrutinised. This article, however, would identify it as a major culprit for the politically regressive aspects of Turkish TV series, especially when it comes to the portrayal of female protagonists.

I have chosen to focus on Our Story, as it is one of the internationally most successful adaptations in our current era when Turkish television tends to be predominated by adapted TV series, but more importantly, because the sharp thematic and narrative divergences of Our Story from its original Shameless allow us to distinguish some of the central characteristics of Turkish television series. After a brief overview of contemporary Turkish television, the political culture of neoliberalism and nostalgia, the first part of the textual analysis would focus on the major similarities and differences of Our Story from Shameless in order to pinpoint the centrality of nostalgia and melancholia in the series' narrative frame, and also to investigate cultural implications of their audience appeal in neoliberal times. The second part is dedicated to the critical investigation of nostalgia and melancholia in Turkish TV series regarding the ways they serve to romanticize and celebrate repressive gender roles.

\section{Rising Popularity of Turkish Television Series}

Turkish TV series have reached unprecedented popularity over a wide region, and Turkey emerged as the biggest TV program exporter after the USA in 2014. ${ }^{6}$ Revenues from TV exports increased from 100 thousand dollars in the early 2000 's ${ }^{7}$ to over 400 million dollars. ${ }^{8}$ Despite the political turmoil and rising economic problems of recent years in Turkey, export revenues and global viewership of Turkish TV series continued to rise. ${ }^{9}$ In total, more than 150 Turkish series have been screened in more than 140 countries, reaching an estimated audience of over 400 million people. ${ }^{10}$ These staggering statistics prompted substantial academic and journalistic interest in studying Turkish TV dramas. It is argued that in the Balkans and Eastern Europe, Turkish TV series have a nostalgic appeal with their portrayal of strong family bonds and groundbreaking love stories, serving as reminders of lost values. ${ }^{11}$ It is also suggested that a major source of appeal for Turkish television series is their strong female protagonists, who serve as sources of inspiration and role models for young women who encounter relatable circumstances in their lives. ${ }^{12}$ 
Marwan Kraidy and Omar Al-Ghazzi argue that two essential charms of Turkish TV series in the Middle East is that they "conjure up an accessible modernity" that incorporates Islam, and they produce a "counter-hegemonic narrative that puts Middle Easterners in the role of heroes." ${ }^{13}$ It is also widely argued that a major source of the appeal of Turkish TV series is the "cultural proximity" Turkey shares with the countries in the Middle East and the Balkans. ${ }^{14}$ Similarly, Zafer Yörük and Pantelis Vatikiotis claim that it is Turkey's ambivalent identity, situated between the West and the East, and its fragile fusion of various identity markers that allows it to be simultaneously successful in the Middle East and Balkans. ${ }^{15}$

It is not a feasible scholarly endeavour to fully account for the cultural work of every one of over 140 exported Turkish TV series due to their considerable political, thematic and stylistic variations. There are also outliers like Fatmagül'ün Suçu Ne? (2010-2012), which has obtained record-breaking fame in Spain by 2018, enlarging the Turkish series' zone of influence outside of the Global South and Eastern Europe. Previous studies enlighten different facets of the Turkish TV series' rising international appeal. This article, likewise, does not propose a holistic explanation for Turkish TV series' international success, which is naturally a multifaceted phenomenon but focuses on a neglected aspect of the cultural work they undertake in an effort to explain their contemporary popularity.

Previous studies on Turkish TV series primarily rely on interviews or audience ethnography, as they focus on investigating the differing audience responses to Turkish TV series. ${ }^{16}$ Additionally, the industrial and politicaleconomic factors are also investigated to explain the rising global popularity of Turkish TV series. ${ }^{17}$ Though certainly revealing, these prior studies do not pay significant attention to the textual fabric of Turkish TV series. As Michelle Phillipov indicates, ethnographic and interview-based methods reveal aspects of popular media that can be verbalized and articulable; however, it is the close examination of textuality that provides insight into a more complex terrain of interconnections between media texts and the socio-cultural phenomena. ${ }^{18}$ I believe we can best identify the narrative and thematic particularities of Turkish TV series that allow them to resonate with the desires of a contemporary international audience base through close textual analysis. To study an adaptation as a form of canned programming is important not only because of the increasing number of adaptations in Turkish television, more so because, it is in their differentiation from their originals that the particularities of Turkish TV series crystallize for analysis.

Contemporary Turkish TV series largely follow in the tradition of Turkish audio-visual productions, extending back to the early days of the film and television industry in Turkey. The emphasis on virtue, family and the sacralization of heterosexual love have been some of the central thematic concerns of the Turkish film industry. ${ }^{19}$ In fact, highlighting of moral good and virtue is the central pillar of "melodramatic imagination" 20 or melodramatic mode of storytelling, ${ }^{21}$ and is widely encountered in the global mediascape. Thus, the current massive international popularity of Turkish TV series is not caused by the invention of new narrative strategies or filmmaking techniques, and, in that regard, Turkish series offer no substantial novelty. To understand their appeal, we should relate the Turkish TV series' thematic concerns with contemporary global socio-cultural processes of change and alienation in neoliberal times. Hence, this article examines Our Story in correspondence with the culture of neoliberalism as a major unifying factor of the diverse regions of the world, and as a key reason for the contemporary popularity of Turkish TV series.

\section{The Age of Nostalgia and Melancholia Under Neoliberalis m}

Neoliberalism is based on the free market and entrepreneurial values, and it has been the dominant socio-economic and political paradigm in an increasingly globalized economic system. ${ }^{22}$ Accompanying the operations of the global capital, we see a concomitant increase in the promulgation of cultural values associated with the functioning of the 
neoliberal economy. Neoliberalism should be considered as a political project of embedding market values in domains of social, cultural and political life. ${ }^{23}$ The ideal neoliberal subject is conceived as "a free and autonomous atom of self-interest" 24 and neoliberalism operates by fostering the belief that every individual is capable of achieving success and satisfaction through their individual and self-seeking efforts. ${ }^{25}$

It is argued that the current historical moment can be described as an age in which the "predominance of the individual over the collective" reaches its high point. ${ }^{26}$ It is even argued that we have been witnessing "a social Darwinist reconfiguration of priorities, policies and outcomes," that implicitly endorses the notion that only the fittest and the

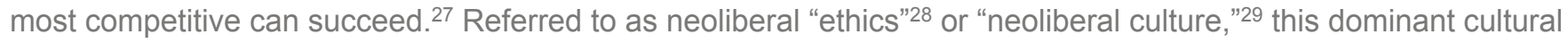
paradigm enhances contest and competition as the main principles of governance of individual and social activity. ${ }^{30}$ Turkey has also undergone a rapid wave of neoliberal restructuring that dramatically reshaped cultural life. ${ }^{31}$ Since the 1980s, a society of consumerism and instant gratifications has come into being. ${ }^{32}$ Rapidly changing cultural norms have led to post-1980 generations in Turkey often being equated with neoliberal consumerism and selfinterestedness. ${ }^{33}$

A major negative effect of putting personal benefits ahead of social and communal concerns is that often it appears as if "social relationships are reduced to temporary coalitions and use." ${ }^{34}$ Garth Stahl argues that living in the neoliberal world means a constant interplay between "uncertainty, survivalist strategies, unrealistic expectations and new searches for respectability and authenticity." ${ }^{35}$ I believe the contemporary rise of nostalgia in various regions of the world, and nostalgic popular narratives referencing simpler, more innocent times and better days should be seen as a search for "respectability and authenticity," caused by neoliberal economic and cultural restructuring. This search for authenticity in the neoliberal age, I argue, is the prime reason for Turkish series' popularity for the countries and regions that have undergone a particularly dramatic and rapid socio-cultural change.

It is often argued that there has been a recent boom in sentimental narratives about the past, and a general "media obsession with nostalgia" in the global mediascape. ${ }^{36}$ Nostalgia can be defined as a complex affective, emotional and cognitive process that serves to bridge and fuse past and the present. ${ }^{37}$ Its emotional appeal is based on the purveying of individual and collective memories that engender a sense of warmth and stability. ${ }^{38}$ Nostalgic tales can be regarded as protective fictions, providing comfort, especially in times of rapid change. ${ }^{39}$ As Andrea Deciu Ritivoi puts it, "when the present is fraught with pain or discomfort... nostalgia can be a source of relief, an escape into a much happier past symbolically contained in a secure place, the home." 40 However, even though built upon the memory of a past age, nostalgia ultimately concerns present desires and needs rather than the historical reality of the past. ${ }^{41}$

Akin to nostalgia, melancholia can be defined as the human "imaginative capacity to make an unobtainable object appear as if lost." 42 Indeed, nostalgia was initially theorized as a form of melancholy produced by the absence of a well-remembered home. ${ }^{43}$ Melancholia is different from nostalgia because it typically has no fixed referent; it lacks an easily and directly observable object of loss. ${ }^{44}$ We can also distinguish melancholia from mourning, in which the subject acknowledges the irretrievable nature of the missing object. ${ }^{45} \mathrm{In}$ melancholia, the subject is captivated by "a yearning that refuses to conclude." 46 In that regard, melancholy paradoxically "intertwines possession and loss." 47

Turkish canned television is often saturated with melancholia about an unspecified lost object. In Our Story, the narrative takes place in the present moment without any direct reference to Turkey's history or contemporary political conundrums, which facilitates their export as canned productions. The series takes the form of an implicit lamentation for a prior age of warmer and more intense human relations. This is achieved not by referring to a past epoch, but by concentrating on a central protagonist's untainted morality, which can be delineated from her surrounding environment that cherishes above all self-interest and wealth. The character is portrayed as a residual trace of an unspoiled moral foundation that contains and safeguards the essential morality of the polity. In this narrative, reluctance to change and 
adapt to the ways of the neoliberal world calls forth the hope that the melancholic object of loss is still present in a residual form and can be recovered fully in an indefinite future.

\section{Our Story and Turkish Canned Adaptations}

In Shameless and Our Story, the story centres on the female protagonist's challenging life. Burdened by her dysfunctional, alcoholic father and absent mother, she raises and looks after her five younger siblings. A defining characteristic of Shameless is the notion that the series provides an explicit and non-judgmental portrayal of drug use, sex, and the petty crimes of the Gallagher family. ${ }^{48}$ There is no time for, nor any need for shame in the hurried and difficult living conditions, as the Gallagher family struggles for survival in the city. Our Story, however, dramatically shifts this thematic emphasis to stress the morality of the 'Elibol' family, resting on the shoulders of the central protagonist Filiz Elibol (Hazal Kaya). The Elibol family effectively represents a melancholic attachment to an imaginary past due to its remarkable moral difference from an increasingly corrupt world. In this thematic readjustment of the scenario, it is the female protagonist, Filiz, who squarely shoulders the responsibility of being the moral linchpin, not only of the Elibol family but also of an increasingly decadent community.

The title of the series, Our Story, doubly signifies that this is both the untold story of under-privileged and invisible sections of society, but also a story that differs from its original, Shameless. In the first shot of the series, Filiz announces that: "This is our home... and here is our neighbourhood that resembles a village... you wouldn't believe when you see it, but we are in the centre of Istanbul." ${ }^{9}$ As Filiz utters these sentences, the camera first shows their poverty-ridden neighbourhood, before swiftly moving up, panning to reveal that their house is very close to an internationally recognizable spot: the Bosphorus Bridge connecting the two halves of Istanbul. The image of the Bosphorus Bridge with a Turkish flag flying in the middle of the frame opens and closes each episode, serving as the main marker of the series' Turkishness. Thus, this is "our story" in the dual sense that it is the story of the underprivileged, but, additionally, a story different from its original. After the Bosphorus Bridge, the camera swiftly approaches their house again, this time, entering from an open window. The camera opens a window into the life of this poverty-stricken and struggling family, however, instead of providing an explicit depiction of moral complexity, as Shameless does, the intention is to provide a lesson in morality and purity.

In Shameless, the central romance between Fiona Gallagher (Emmy Rossum) and Steve Wilton (Justin Chatwin) starts in the first minutes of the first episode. A stranger steals Fiona's purse in a night club. Steve, watching her dance from above the stairs, gives chase only to fall and injure himself, rather than helping the damsel in distress. Starting with a comedic twist to an oft-repeated conventional melodramatic plot element, their romantic affair continues as more humorous than dramatic, unlike the plot in Our Story. After having casual sex with Steve, Fiona appears uninterested in his further romantic advances, largely because she considers him as rich and spoilt. When she later learns that he earns a living stealing luxury sports cars her attitude changes. Hence, in another significant contrast with Our Story, the male lead's criminal activities are not a big issue for Fiona, rather, they make him more desirable.

Gender relations are a particularly sensitive topic in adaptations. ${ }^{50}$ Our Story significantly deviates from Shameless in the representation of femininity and masculinity. Filiz meets Barış, Steve's counterpart, as she walks to a traditional pre-marriage female-only event, only after her closest friend's insistence. A thief steals her purse as the two are walking on the street. Thus, unlike Fiona, Filiz is not shown dancing and enjoying herself, and throughout the series, no sexual life is portrayed. It is only in the fifth episode that she kisses Barış for the first time. In their first encounter, unlike Steve, Barış catches and beats the thief, and returns Filiz's purse, sidestepping comedic twist of Shameless in favour of a more traditional narrative. The actor portraying Barış is also taller and more muscular than Steve. Hence, narratively and visually, he is portrayed as more of a conventionally protective male lead. 
Filiz never does a morally questionable or 'shameless' deed. For instance, unaware that Barış lives by stealing and selling cars, she naively believes his story that he is a valet. It is a major blow when she finds out several episodes later, as any type of criminal activity is completely unacceptable to her. Shameless' Fiona often appears to be torn between the impulse to follow her personal desires and her responsibilities towards her younger brothers and sisters, but, for Filiz, no such personal confusion exists; she is always self-sacrificially committed to the well-being of her family. She is portrayed as the moral high ground that draws everyone to her higher level. She saves Barış from himself and his troubled past, to create a law-abiding citizen, who abandons his criminal life behind. In a speech in episode 13, accompanied by a dramatic score, Barış tells her that:

It is by you that I learned about thinking others ahead of yourself... All of you think of others and other things before your own best interests. A single smile of your siblings, their happiness is way more important to you than your own happiness. This, this is so important; money, wealth, nothing matters to you. This is such a marvellous, and such an important thing, it is like a miracle. It is something that I have never seen, and never experienced." 51

There are plenty of such moments when the moral virtue embodied especially by Filiz is contrasted to a social order that privileges wealth and self-interest. Other members of the family may go morally astray, but it is with her help that each eventually recovers. In episode 14 , she is utterly devastated on learning that the eldest of her younger brothers is sitting maths exams in place of others for money. Her brother says that he does it for the family and her. She tearfully replies: "No, this is not how I raised any of you. My brothers cannot do such things. This is theft, counterfeit, this is!"52. Her brother replies sardonically that they will soon go hungry with this logic. She rises and slaps his face, and he storms out, berating himself in the streets for hurting his sister's feelings. From that moment on, he never repeats this or gets involved in any other illegal activity.

This is a dramatically different portrayal of the central female protagonist when compared to Shameless' Fiona, who, for instance, in the third episode of the second season, treats her siblings to dinner with $500 \$$ stolen from an unattended handbag she finds in the subway. She briefly discusses selling the bag on eBay with the eldest of her younger brothers, before eventually deciding to return it to its owner. Rather than a non-judgmental look into moral complexity, Filiz is marked by her unmatched moral values, which turns her into a standard-bearer of morality for a community in the process of moral degeneration. She is the solid moral cornerstone of the family, and the community shaken by the waves of socio-cultural change. In Filiz, we glimpse a nostalgic and melancholic vision of moral purity we believe may have existed in some imaginary time before, for the loss of which we can melancholically lament, and still hope for its eventual return.

There is a visual and narrative match between the opening shot of Our Story in the first episode and its last shot, which concludes the series, in episode 70. In the first episode, the camera slowly approaches the Elibol family's house in their deprived neighbourhood and enters through an open window. In the last scene, the entire family sit together and laugh in unison, despite facing many ordeals. By the ending, Barış and Filiz are married, most other members of the large family find the love of their life, and even their alcoholic father is redeemed. The camera retreats slowly and leaves their house from an open window as in the beginning. From an above shot, their unidentifiably common house appears to signify that this is, after all, the story of one lower-class family, similar to many others across the city.

In theorizing the experience of modern tourism, Dean MacCannell argues that traveling abroad in modern capitalism serves the purpose of catching "a glimpse of" authenticity reflected in the simple "chastity or purity of others." 53 Likewise, Our Story offers the audience a voyage into the house and life of the Elibol family. As we enter and leave their house, their story allows us to catch a glimpse of purity that we melancholically believe is missing in today's world, but we have never completely lost. The Elibol family's story, thus, becomes "our story," in the sense that even though virtue and authentic human bonding are in decay under the neoliberal pressure of intense competition and hyper-individualism, the series indicates that the object of loss, the authenticity, remains recoverable. 


\section{Nostalgia and Patriarchal Re-Framing in Turkish TV Series}

Both Shameless and Our Story are mixed-genre productions, typical of long-running TV series, but we can observe a greater emphasis on drama rather than comedy in Our Story. The resulting somber tone, a common feature in Turkish adaptations, enables a greater focus on contemporary social issues, mainly the patriarchal oppression and domestic violence. The emphasis on patriarchal oppression is often considered as a prime reason for the popularity of Turkish adaptations as canned programming. However, as can be observed in Our Story, melancholic and nostalgic attachment to an imagined past result in sacralizing hetero-sexual coupling and the large family as women's ultimate sources of commitment, disregarding that these have often been their main sources of oppression.

It is argued that the Turkish series have positively impacted gender relations, especially in the Middle East. ${ }^{54}$ Labelled as a "game-changer," it is claimed that as a direct result of Turkish dramas' popularity, "the number of reported rape cases has grown [and] women are increasingly asserting their right to divorce in unhappy marriages." However, Turkish dramas are also criticized for representing violence against women as exceptional states caused by the actions of some callous men, and that women are often able to escape the cycles of violence through the help of a benevolent male lead. ${ }^{56}$ In this regard, violence against women is represented as an aspect of life beyond the contours of everyday normality, erasing from view the fact that what is deemed as normal entails various and little-mentioned acts of violence and oppression.

In Our Story, we can find traces of engagement with these public and academic criticisms of the Turkish TV series. Patriarchal oppression is represented as a pervasive aspect of life that affects all major female characters. In the first episode alone, there are five scenes of verbal and physical violence against women by their abusive boyfriends, husbands, or ex-husbands. The series also tends to blur the boundaries between callous men who harm, and benevolent men who protect or save women. For instance, the series points out that the central character, Filiz, suffers because of the actions of men in her family. In the final minutes of the first episode, Filiz's father and younger brothers all yell at Barış to get out of Filiz's life. Filiz sadly tells him that: "Can't you see, I don't have a life of my own... We cannot be together." ${ }^{57}$ Rather than a brute outsider, it is her male siblings, otherwise sympathetically portrayed, who cause her substantial suffering in delimiting her life.

In a different storyline, one of Filiz's young brothers falls in love with an older, married woman, herself a victim of domestic violence. He dreams of the day when he will save her from that terrible man and marry her. One day, she abandons her abusive husband, taking refuge in a new house. Hikmet buys her many presents with his hard-earned money; a bouquet of roses, and even an engagement ring. In episode 24, as Hikmet falls to his knees to propose, she angrily slaps the ring out of his hand. This is the first time that we see the long-abused woman yelling: "I want neither you nor Asım [her husband]. What is the difference between you and him? Enough! Go! Why don't you understand from no?... Have you asked me if I want any of these things?"58 Hence, the series does not always rely on a neat separation between the callous men and the good male leads, but rather gestures towards an understanding that everyday life activities of well-meaning men can also be a source of oppression for women.

The opening narrative voice in the first episode of Our Story belongs to Filiz, marking her centrality to the story from the beginning, whereas in Shameless, we first hear Fiona's father Frank introduce the members of his large family to the audience. Addtionally, in Our Story, the narrative appears more focused on Filiz with greater screening time for her in comparison to Fiona. However, as can be frequently observed in Turkish TV series, Filiz's celebrated puritanical and self-sacrificial portrayal is bent towards restricting women's life choices, largely excluding them from the material and sensual pleasures of life, ultimately, making it very easy for women to be labelled as immoral antagonists unless they follow a very rigid code of conduct in regard to personal morality. For instance, Filiz is regularly contrasted with female antagonists, who are typically young, wealthy and well-educated women in Barış' entourage. Unlike Filiz, these women have a sexual life, and they are depicted as overly concerned with the material aspects of life. 
Furthermore, Filiz's portrayal gets a more conservative edge as the story progresses. Patriarchal re-framing is an intrinsic characteristic of the romance as a genre, ${ }^{59}$ and, similarly, we witness Filiz's gradual transformation from an indepedent and somewhat rebellious person to a docile and obedient lover through her romantic attachment to Barış. It is ultimately the nostalgic and melancholic attributes of the narrative that severely limit the representational possibilities for Filiz as the central protagonist. Hence, even though female-centred Turkish canned TV series open up a space for the representation for patriarchal oppression, bringing it into the forefront of public debate, they, nonetheless, reproduce conservative standards and patriarchal relations of domination in allowing its female protagonists only a limited repertoire of roles through sacralizing a nostalgic fixation with large patriarchal families and committed heterosexual relationships.

\section{Conclusion}

Turkish series' international success has multiple socio-cultural, political and industrial reasons. In this article, I focused on and examined one major and previously neglected frame of analysis in order to explicate their appeal in such diverse regions as Eastern Europe, the Balkans, South America, South and Southeast Asia, and the Middle East. I argued that it is the culture of neoliberalism that creates a demand for Turkish TV series. As people from newly industrialized and developing countries have a harder time to come to terms with the socio-cultural effects of neoliberal hyper-individualism and increased pressure for competitiveness, it is primarily in these regions that Turkish series have attained success. With their nostalgic and melancholic narrative frames, Turkish TV series respond to this collective sense of unease in the face of swift and uprooting socio-cultural change in the age of neoliberalism.

In his seminal study, Peter Brooks argues that melodrama emerged "in a world where the traditional imperatives of truth and ethics have been violently thrown into question." 60 In response to swift societal change, the melodramatic mode of storytelling relies on the "staging, unearthing or the rediscovery of innocence" 61 and it corresponds to a "search for identity, social order, and clear moral values." 62 As demonstrated in this article, Our Story is primarily a melodramatic narrative about the staging and the rediscovery of innocence, and contemporary Turkish series do not, in essence, diverge from the narrative tradition of melodrama, which has historically been the primary basis of storytelling in Turkish cinema and television. Turkish series' charm for the international audience stems from a renewed desire for consuming melodramatic tales for people living under the pressure of neoliberal culture of hyper-individualism and competitiveness. Thus, it is their conventionality, rather than novelty, which distinguishes Turkish TV series in a changing global mediascape.

Even though Our Story copies every major plot element of Shameless, it thematically re-structures the story into a melodramatic tale of innocence, virtue, and redemption. Through its sharp differentiation from its original that we can isolate central distinguishing characteristics of Turkish TV series. The Turkish television industry uses a relatively limited number of actors who often portray similar characters across several popular TV series. News reports indicate that audiences in South America eagerly awaited the broadcasting of Our Story as Hazal Kaya's new show. ${ }^{63}$ Shortly after the final episode, she appeared in the leading role in another Turkish series, portraying a similar character. Hence, even when reproducing the script of foreign shows, Turkish series are still thematically more akin to each other. With actors successively portraying similar roles in a somewhat closed-circuit of multiple series, the Turkish TV industry tends to recurrently offer the international audiences nostalgic and melancholic narratives.

Previous studies on Turkish TV series often emphasize the notion of "cultural proximity" and the ambivalent nature of Turkish identity to explain the Turkish series' popularity in the Middle East and the Balkans. ${ }^{64}$ In this article, I do not completely negate the cultural proximity theory, instead, I argue that the international popularity of Turkish TV series in multitudes of countries beyond the Middle East and the Balkans necessitates re-consideration and re-framing of the 
concept. Rather than geographical closeness or historical ties, it is the swift neoliberal transformation that should be identified as a major thread of cultural proximity, uniting the regions where Turkish series have achieved remarkable success. Hence, I argue that the common link between these wide apart regions is their experience of swift neoliberal transformations, and the resulting cultural dilemmas generate a desire for nostalgic and melancholic tales provided by the Turkish television industry.

We should, nonetheless, be cautious in approaching Turkish TV series' critical potentials against the culture of neoliberalism. Nostalgic and melancholic attachment to an imagined epoch of strong familial bonds, authentic human ties, and passionate heterosexual romances also means central female protagonists are allowed only a limited range of roles as the cornerstones of collective morality. As one recent extensive study on the representation of women in Turkish television series indicates, despite similarities in the visibility of female and male protagonists, women are typically relegated to secondarized roles and are associated with family, emotionality, and housekeeping. ${ }^{65}$ Even when the Turkish series explicitly criticizes aspects of patriarchy as Our Story, they fail to touch on some of its root causes, for which, nostalgic and melancholic narrative frames that endorse conservative understandings of femininity should be identified as major reasons. Therefore, despite containing critical potentials against contemporary neoliberalism and patriarchy, Turkish TV series ultimately serve to re-legitimize patriarchal relations of domination.

\section{Notes}

1. A partial list of recent boom in Turkish adaptations of foreign TV shows would include Ufak Tefek Cinayetler (2017-2018), Umutsuz Ev Kadınları (2011-2014), Kadın (2017-), Küçük Sırlar (2010), Intikam (2013-2014), Medcezir (2013-2015), Bir Aile Hikayesi (2019), and Avlu (2018-), which are adapted respectively from Big Little Lies (2017-), Desperate Housewives (2004-2012), Dawson's Creek (1998-2003), Gossip Girl (2007-2012), Revenge (2011-2015), The O.C. (2003-2007), This Is Us (2016), Woman (2013), and Wentworth (2013-). Turkish TV producers also adapted over thirty South Korean dramas in recent years, such as Paramparça (2014-2017), Hayat Şarkısı (2016-2017), Adını Feriha Koydum: Emir'in Yolu (2012), Bir Aşk Hikayesi (2013-2014), and Anne (2016-2017), which are adapted from Autumn in My Heart (2000), Flames of Desire (2010-2011), The Man from Nowhere (2010), I'm Sorry I Love You (2017), and Mother (2018).

2. Merve Mutlu Dorak, "Bizim Hikaye, Kadın ve Anne Dizileri Latina Turkish Awards Ödüllerine Damgasını Vurdu!," Diziler, March 15, 2019, https://www.diziler.com/haber/bizim-hikaye-kadin-ve-anne-dizileri-latina-turkish-awards-odullerinedamgasini-vurdu-19548

3. The other two series that received accolades in Latin American Awards, Kadın (2017-) and Anne (2016-2017), are likewise Turkish adaptations of foreign television series, demonstrating the success of adaptations as canned TV.

4. Nina Maria Paschalidou, dir., Kismet: How Turkish Soap Operas Change the World, 2014, Agitprop, Al-Jazeera, Anemon Productions, https://www.youtube.com/watch?v=NX8Un4nneXg\&vl=en

5. Susan Stewart, On Longing: Narratives of the Miniature, the Gigantic, the Souvenir, the Collection (Durham: Duke University Press, 1984); Janelle L. Wilson, Nostalgia: Sanctuary of Meaning (Lewisburg: Bucknell University Press, 2005$), 23$.

6. Feride Yalav-Heckeroth, "8 Soap Operas to Make You Fall in Love with Turkish TV," Culture Trip, March 10, 2017, https:/l theculturetrip.com/europe/turkey/articles/8-soap-operas-to-make-you-fall-in-love-with-turkish-tv/

7. Rhonda Richford, "MIPCOM: Turkey Replaces Israel as TV's New Hot Market," The Hollywood Reporter, December 10, 2015, https://www.hollywoodreporter.com/news/mipcom-turkey-replaces-israel-as-827656

8. Nick Vivarelli, "Turkish TV dramas continue to sell despite local turmoil," Variety, April 3, 2017, https://variety.com/2017/tv/ global/turkish-tv-dramas-phi-second-chance-masum-1202019972/

9. Fatima Bhutto, "How Turkish TV Is Taking Over the World," Guardian, September 13, 2019, https://www.theguardian.com/ tv-and-radio/2019/sep/13/turkish-tv-magnificent-century-dizi-taking-over-world?fbclid=IwAR0S3wyWz42FAdirX4M6zOyHtQ4nPakDndf6sJ_kGfdVFE7OqmBDQU1GAg

10. Didem Tali, "An Unlikely Story: Why Do South Americans Love Turkish TV?," BBC, September 8, 2016, https://www.bbc.com/ news/business-37284938

11. https://www.dw.com/tr/d\%C3\%BCnya-t\%C3\%BCrkleri-izliyor/a-19151741

12. Paschalidou, Kismet.

13. Marwan M. Kraidy and Omar Al-Ghazzi, "Neo-Ottoman Cool: Turkish Popular Culture in the Arab Public Sphere," Popular Communication 11, no. 1 (2013): 17. 
14. Miriam Berg, "The Importance of Cultural Proximity in the Success of Turkish Dramas in Qatar," International Journal of Communication 11, (2017): 3415-30.

15. Zafer Yörük and Pantelis Vatikiotis, "Turkey, the Middle East \& the Media. Soft Power or Illusion of Hegemony: The Case of the Turkish Soap Opera Colonialism," International Journal of Communication 7, no. 25 (2013): 2379.

16. For instance, Eylem Yanardağoğlu and Imad N. Karam, "The Fever That Hit Arab Satellite Television: Audience Perceptions of Turkish TV Series," Identities 20, no. 5 (2013): 561-79.

17. Bilge Yesil, "Transnationalization of Turkish Dramas: Exploring the Convergence of Local and Global Market Imperatives," Global Media and Communication 11, no. 1 (2015): 43060.

18. Michelle Phillipov, "In Defense of Textual Analysis: Resisting Methodological Hegemony in Media and Cultural studies," Critical Studies in Media Communication 30, no. 3 (2013): 211.

19. Dilek Kaya Mutlu, "Between Tradition and Modernity: Yeşilçam Melodrama, its Stars, and their Audiences," Middle Eastern Studies 46, no. 3 (2010): 417-31.

20. Peter Brooks, The Melodramatic Imagination: Balzac, Henry James, Melodrama and the Mode of Excess (New Haven, CT: Yale University Press, 1976).

21. Linda Williams, "Melodrama Revised," in Refiguring American Film Genres: History and Theory, ed. Nick Browne (Los Angeles and London: University of California Press, 1998), 42.

22. Julien Mercille and Enda Murphy, Deepening Neoliberalism, Austerity, and Crisis: Europe's Treasure Ireland (Basingstoke: Springer, 2015), 1-3.

23. Jenna Ng, "Neoliberalism and Authoritarianism in Singaporean Cinema: A Case Study of Perth," in Neoliberalism and Global Cinema: Capital, Culture, and Marxist Critique, eds. Jyotsna Kapur and Keith B. Wagner (London: Routledge, 2011$), 262$.

24. Trent H. Hamann, "Neoliberalism, Governmentality, and Ethics," Foucault Studies 6, (2009): 38.

25. Patricia Ventura, Neoliberal Culture: Living with American Neoliberalism (London: Routledge, 2016), 11.

26. Jason Read, The Politics of Transindividuality (Leiden: Brill, 2016), 1.

27. Stephen Gill, "Theorizing the Interregnum: The Double Movement and Global Politics in the 1990s," in The Global Resistance Reader, ed. Louise Amoore (London: Psychology Press, 2005), 56.

28. Bruno Amable, "Morals and Politics in the Ideology of Neo-Liberalism," Socio-Economic Review 9, no. 1 (2011): 3-30.

29. Ventura, Neoliberal Culture, 1.

30. Dieter Declercq, "These People Are the Enemy: The Moral Responsibilities of Film and Television History Within the Humanities," in Cinema, Television and History: New Approaches, eds. Laura Mee and Johnny Walker (Cambridge: Cambridge Scholars Publishing, 2014), 112.

31. Çaglar Keyder, "The Turkish Bell Jar," New Left Review 28, no. 65 (2004): 67.

32. Nurdan Gürbilek, The New Cultural Climate in Turkey: Living in a Shop Window (London: Zed Books Ltd., 2013$), 96$.

33. Demet Lüküslü, "To Be a Child in the 1980s in Turkey: Construction of Generational Memory and Nostalgia Through Cyberspace," in Digital Transformations in Turkey: Current Perspectives in Communication Studies, ed. Banu Akdenizli (Lanham: Lexington Books, 2015), 66.

34. Declercq, "These People Are the Enemy": 111

35. Garth Stahl, Identity, Neoliberalism and Aspiration: Educating White Working-Class Boys (London: Routledge, 2015), 19.

36. Katharina Niemeyer, Media and Nostalgia: Yearning for the Past, Present and Future (Basingstoke: Springer, 2014$), 2$.

37. Andrea D. Ritivoi, Yesterday's Self: Nostalgia and the Immigrant Identity (Lanham: Rowman \& Littlefield Publishers, 2002), 30

38. Wilson, Nostalgia, 23.

39. Martin Baake-Hansen, "Nostalgia and Nostophobia: Emotional Memory in Joseph Roth and Herta Muller," in Structures of Feeling: Affectivity and the Study of Culture, eds. Devika Sharma and Frederik Tygstrup (Berlin: Walter de Gruyter GmbH \& Co. KG, 2015), 117.

40. Ritivoi, Yesterday's Self, 36

41. Stewart, On Longing, 23.

42. Giorgio Agamben, Stanzas: Word and Phantasm in Western Culture (Minneapolis: University of Minnesota Press, 1993$), 20$.

43. Christoph Ehland and Stephan Kohl, "Commercializing Melancholy: The National Trust," in The Literature of Melancholia: Early Modern to Postmodern, eds. Martin Middeke and Christina Wald (Lanham: Springer, 2011), 130.

44. Anne Enderwitz, Modernist Melancholia: Freud, Conrad and Ford (Lanham: Springer, 2015), 8.

45. Peter Schwenger, The Tears of Things: Melancholy and Physical Objects (Minneapolis: University of Minnesota Press, 2006), 11.

46. Ibid., 175 .

47. Ibid., 11.

48. Glen Creeber, “'The Truth Is Out There! Not!': Shameless and the Moral Structures of Contemporary Social Realism,” New Review of Film and Television Studies 7, no. 4 (2009): 435-436.

49. All translations from Turkish to English belong to the author. "Burası bizim evimiz... Burası da bir köye benzeyen mahallemiz.... Görünce inanmazsınız ama, burası İstanbul'un göbeği." 
50. Fien Adriaens and Daniel Biltereyst, "Glocalized Telenovelas and National Identities: A 'Textual Cum Production' Analysis of the 'Telenovelle' Sara, the Flemish Adaptation of Yo soy Betty, la fea,' Television \& New Media 13, no. 6 (2012): 555.

51. "Kendinden çok başkasını düşünmek ben sizde tanıdım...hepiniz, kendinizden başka her şeyi, herkesi düşünüyorsunuz... Kardeşlerinin bir gülmesi, bir mutlu olması senin mutluluğundan kat kat daha önemli. Bu kadar, o kadar büyük bir şey ki, para pul cart curt, hiçbir şey umurunuzda değil, bu çok büyük bir şey, çok önemli bir şey, bu mucize gibi, bu benim hiç görmediğim, hiç tatmadığım bir şey."

52. "Olmaz, ben hiçbirinizi böyle yetiştirmedim. Benim kardeşlerim böyle şeyler yapamazlar. Bu hırsızlık, sahtekârlık bu."

53. Dean MacCannell, The Tourist: A New Theory of the Leisure Class (Berkeley: University of California Press, 2013/1976), 41.

54. Paschalidou, Kismet.

55. Shelina Janmohamed, Generation M: Young Muslims Changing the World (London: I.B. Tauris, 2016$), 180$.

56. Feyza Akınerdem and Nükhet Sirman, "Kadın Cinayetlerinin Sorumlusu Diziler midir?" [Are TV series responsible for female murders?], Sendika.org, August 31, 2019, http://sendika63.org/2019/08/kadin-cinayetlerinin-sorumlusu-diziler-midirfeyza-akinerdem-nukhet-sirman-recel-559618/

57. "Ya görmüyor musun, benim kendime ait bir hayatim yok... biz bir şey yaşayamayız işte."

58. "Seni de Asım'ı da istemiyorum. Senin ondan ne farkın var? Yeter! Git! Siz neden hayırdan anlamıyorsunuz, ben çok yoruldum, yoruldum artık, bunları istiyorum diye bana sordun mu bütün bunları?”

59. Janice A. Radway, Reading the Romance: Women, Patriarchy, and Popular Literature (Chapel Hill: University of North Carolina Press, 1984).

60. Brooks, The Melodramatic Imagination, 15.

61. Williams, "Melodrama Revised," 55.

62. E. Ann Kaplan, Trauma Culture: The Politics of Terror and Loss in Media and Literature (New Brunswick: Rutgers University Press, 2005), 72.

63. Ece Er, "Bizim Hikaye'yi Sadece Biz Mi Bekliyoruz Sanıyorsunuz?" [Do you think only we are waiting for our story?] Televizyon Gazetesi, September 14, 2017, https://televizyongazetesi.com/bizim-hikayeyi-sadece-biz-mi-bekliyoruz-saniyorsunuzbu-aksam-baska-ulkelerde-de-merakli-bir-bekleyis-var/153317

64. Berg, "The Importance of Cultural Proximity"; Yörük and Vatikiotis, "Turkey, the Middle East \& the Media".

65. İrem İnceoğlu and Elif Akçalı, "Televizyon Dizilerinde Toplumsal Cinsiyet Eşitliği Araştırması" [Survey of gender equality in TV series], TÜSIAD Televizyon Dizilerinde Toplumsal Cinsiyet Eşitliği Projesi 03 - 591 (2018): 1-58.

\section{Biography}

Deniz Zorlu has been teaching in the Department of Media and Communication and in the Department of Cinema and Digital Media at Izmir University of Economics, Turkey since September 2018. He received his Ph.D. from Queen's University Cultural Studies program at Kingston, Canada in November 2017. In his doctorate thesis, he analyzed the ways popular Turkish television series engage with and affect the processes of socio-cultural change in Turkey. His primary research interests include the examination of popular media productions with a specific focus on Turkish television series and the political uses of social media sites in contemporary Turkey. His articles on television and social media are published or are slated for publishing in peer-reviewed journals such as New Review of Film and Television Studies, Gender Forum: An Internet Journal for Gender Studies and Masculinities: A Journal of Culture and Society. 